\title{
THE ANALYSIS OF LIFE STRATEGIES OF POPULATIONS OF ENTOMOPATHOGENIC FUNGI IN GARDENS OF EXCLUSION ZONE OF THE CHERNOBYL NUCLEAR POWER PLANT
}

\section{Drozda Valentin}

National University of Life and Environmental Sciences of Ukraine, Kyiv, Ukraine

\author{
Received 11. 5. 2017 \\ Revised 22. 5. 2017 \\ Published 27. 11. 2017
}

The aim of researches was study the species composition, life strategies, spreading, ecology and biology of entomopathogenic fungi in gardens of exclusion zone of the Chernobyl nuclear power plant in context of the Chernobyl disaster, associated with the biodiversity of not only plants, animals, but also microorganisms. The analysis of some aspects of relationship between entomopathogenic fungi and various stages of development of the codling moth (Laspeyresia pomonella L.) was carried out, also investigated their saprophyte strategy. A row of key provisions that has relevant to theoretical and applied issues, including the specific factor of long-acting effect of ionizing radiations was allocated. The entomopathogenic fungi, as typical r-strategists, are characterized by signs of K-selection, develop in mature, climax microbial system on the biomass of caterpillars and pupae of the codling moth were shown. In addition, these entomopathogens can to develop in saprophytic conditions. The problems, associated with the implementation of tactics of reproduction, survival and trophic connections by fungi were discussed. The life strategy of the fungus - Paecilomyces farinosus A.H.S.Br. \& G.Sm. was described in detail. The attention was focused on his dominance among other fungi with pronounced trophic expansion. The ecological adaptation and plasticity of Paecilomyces farinosus in saprophytic conditions are manifested clearly in spreading of pathogen in ecosystems of exclusion zone of the Chernobyl nuclear power plant. It is emphasized that one of the vectors of spreading of fungus is insects. The status of entomopathogenic fungi in ecosystems of exclusion zone of the Chernobyl nuclear power plant is determined by the balance of biomass and trophic resources, also the information role in this specific biocenotic structure.

Keywords: entomopathogenic fungi; R- and K-selection; the codling moth; life strategies; saprophytes; caterpillars; pupae

\section{Introduction}

An important problem of modern ecology is studing of the microflora, especially natural ecosystems. The urgency of this problem consists of not only in the definition their species identification, but also with the search and isolation of highly virulent entomopathogenic forms, which associated trophically with certain complex of insect-phytophages, inhabiting in different biogeocenoses. As we see it, researches, conducting in ecosystems of exclusion zone of the Chernobyl nuclear power plant have a big interest. The unique combinations of various factors with specific radiation background are main reason for formation of the species diversity of entomopathogenic fungi with original metabolic and trophic characteristics.

*Corresponding author: Valentin Drozda, National University of Life and Environmental Sciences of Ukraine, Kyiv, Ukraine, $\triangle$ biomethod@quality.ua 
The fungi are represented widely systematically as pathogens of insects and mites - from primitive water forms to highly organized terrestrial (Evlaxova, 1974). Currently, parasites of insects and mites are known in all four classes (of phycomycetes to imperfect ones). The greatest quantity of entomopathogenic fungi belongs to the ancestors of Entomophthorales, Monilialis and Fungi imperfecti. The total quantity of entomopathogenic fungi reaches of 530 (Ignoffo, 1967; Ferron, 1967).

It is substantially that they can become the members of the biocenosis, in which they are included, and also reproduce independently. The fungi can to infect to insects in various ways, namely contact through surface, by absorbing spore and vegetative mass with food. It is increase the chances of infection.

The fungi can preserve in various forms under adverse habitat conditions as sporangia, resting spores, sclerotia and fruiting bodies, compact mass of intertwined vegetative hyphae of pseudosclerotic type, and also in the saprophytic state (Fassatiova, 1957; Androsov, 1986). The fungi infect relatively small quantity of useful insect species, which makes it possible to use them widely in the practice of protecting plants from insect-phytophages (Drozda, 2009; Drozda et al., 2014). The most of entomopathogenic fungi are succumb to cultivation on nutrient media and can be prepared in the form of biological preparations. It is an essential feature of entomopathogenic fungi (Drozda, 2009).

The aim of researches was study the species composition, life strategies, spreading, ecology and biocenology of entomopathogenic fungi in gardens of exclusion zone of the Chernobyl nuclear power plant in context of the Chernobyl phenomenon in solving theoretical problems, associated with the biodiversity of not only plants, animals, but also microorganisms. The conducting of thorough monitoring of entomopathogens, trophically and ecologically related with populations of the codling moth (Laspeyresia pomonella L.) (Lepidoptera, Tortricidae), was one of the aims.

\section{Material and methodology}

During ten years ecological and physiological monitoring of populations of the codling moth in gardens of exclusion zone of the Chernobyl nuclear power plant was conducted. The collections of various stages of the phytophage (eggs, diapausing caterpillars and pupae) using known developments were carried out (Jagues, Mac Lellan, 1965; Gafurova, 1971; Ferro et al., 1975; Labanowski, 1981; Drozda, 2009, 2014, 2016).

The microflora of eggs of the codling moth was studied by way of sowing of the homogenome on nutrient media. The sowing was included 80-100 eggs simultaneously. The fungal microflora of caterpillars of younger, middle and older ages and pupae of the codling moth was investigated (Krasil'nikov, 1958; Weiser, 1972).

The experimental researches were carried out in the Ukrainian laboratory of quality and safety of products of the agro-industrial complex of Ukraine. Behind stages of development in ontogenesis the microflora of the codling moth was studied. The large quantity of material was investigated: healthy, infected, dead caterpillars, pupae and adults of the codling moth. The sowings were produced from leaves and bark of apple, soil of root zone and fruits for establishing of connection between the microflora of phytophage and the microflora of habitat. The isolated entomopathogenic fungi were grouped according to morphological and cultural-biochemical features. All cultures and strains of fungi were determined up to the species. The outer integuments of the caterpillars and their internal contents were examined under sterile conditions. Mummified corpses of caterpillars and pupae after 
preliminary flame treatment were placed in moist chambers. The fungi were isolated to pure culture after the appearance of aerial mycelium on the surface of corpses (Evlaxova and Shveczova, 1966).

The life strategies of entomopathogenic fungi were investigated on the basis of analysis of twelve original test characteristics by example of populations of the codling moth (Macarthur and Wilson, 1963; Pianka, 1972; Chulkina, 1991; Drozda, 2015; Drozda and Sagitov, 2015; Drozda and Gojchuk, 2015).

\section{Results and discussion}

The long-term experiments made possible to distinguish and identify practically whole fund of entomopathogenic fungi, which related ecologically and trophically with the codling moth. These are parasitic forms, developing mainly on caterpillars and pupae of phytophage. In addition, the certain part of fungal populations existed and functioned in the saprophytic state, utilizing dead organic substrate.

The results of researches were showed, that in most cases the isolated strains of fungi from healthy caterpillars are soil saprophytes or phytopathogens. From of 263 the examined healthy caterpillars of the codling moth were found fungi in 21 , which is $7.9 \%$.

The sick and deceased caterpillars are more susceptible to fungal infections, as shown by analysis of the microflora. $91.6 \%$ of all fungal pathogens were accounted on them, on stage of pupa $-6.2 \%$, adult $-2.2 \%$. The virulence level of fungi depends on many factors. We have established (Drozda and Sagitov, 2015), that the determining factor of stability of caterpillars of the codling moth and other species with family Tortricidae depends on the titer of tannin in composition of cocoons. Tannin is strongest fungistatik, ensuring the viability of physiologically full-fledged part of populations of the codling moth. As researches were shown, synoptic anomalies perform only modifying role among factors of mortality of the codling moth. They cut off preferentially the physiologically defective part of the population.

The materials of Table 1 illustrate quantity of species of entomopathogenic fungi and the degree of their dominance. The overwhelming dominance of fungi with spore mycelium was established. Only $6.3 \%$ of fungi with non-spore mycelium from whole fund were allocated. Obvious overwhelming dominance of fungus - Beauveria bassiana (Bals.) Vuill. was observed. From total stock of infected and dead caterpillars and pupae of the codling moth (1286 individuals), 47.9\% was assigned to B. bassiana (Bals.) Vuill. Among other species, between 7.4 and $12.6 \%$ were noted Mucor hiemalis, Paecilomyces farinosus and species from row of Penicillium. These representatives were characterized by pronounced mixed life strategy. The niches inhabited by them are caterpillars and pupae of the codling moth for parasitic forms, plant organic substrate for saprophytic forms.

It should be noted, that similar analysis of populations of entomopathogenic fungi, isolated from the targeted substrates of industrial gardens - of populations of the codling moth outside exclusion zone of the Chernobyl nuclear power plant was shown significant differences in them. Only eleven species of fungi were in industrial gardens. Some regularities of catalytic functions of fungi were studied from the point of view of ecological adaptation that allows considering their substrate specialization (Kozhevin, 2004; Vinogradova and Kozhevin 2011). In first time, this phenomenon was studied in forest biogeocenoses (Androsov et al., 1981). Our researches have shown that the transition of some entomopathogenic fungi to saprophytes allows increasing significantly the ecological niches, approached to fundamental. Also the metabolic phenomenon of synthesis of cellulose, pectinase 
and amylase was confirmed. They are characterized by mixed life strategy with accent on parasitism, in the case of high strength of populations of the codling moth. The ontogenesis of the codling moth is accompanied by variety of stressful situations. Its life strategy is destabilized by feed deficit and synoptic anomalies.

Table 1 The species composition of fungi, isolated from dead caterpillars and pupae of the codling moth, which collected in gardens of exclusion zone of the Chernobyl nuclear power plant

\begin{tabular}{|l|c|c|c|c|c|}
\hline \multirow{2}{*}{ The species of entomopathogenic fungi } & \multicolumn{5}{|c|}{ The individuals infected with fungi were detected } \\
\cline { 2 - 6 } & $\mathbf{2 0 1 2}$ & $\mathbf{2 0 1 3}$ & $\mathbf{2 0 1 4}$ & total & $\%$ \\
\hline Alternaria tenuis Nees. & 7 & 16 & 14 & 37 & 2.8 \\
\hline Aspergillus niger v. Teigh. & 5 & 4 & 4 & 13 & 1.0 \\
\hline Aspergillus flavus Link. & 2 & 1 & 3 & 6 & 0.5 \\
\hline A. parasiticus Speare. & 14 & 11 & 9 & 34 & 2.9 \\
\hline Aspergillus sp. & 6 & 3 & 7 & 16 & 1.2 \\
\hline Beauveria bassiana (Bals.) Vuill. & 156 & 234 & 219 & 609 & 47.9 \\
\hline Cladosporium elegantulum Link ex Fr. & 9 & 11 & 13 & 33 & 2.6 \\
\hline Cladosporium sp. & 7 & 4 & 6 & 17 & 1.3 \\
\hline Fusarium oxysporum Schlecht. & 4 & 9 & 11 & 24 & 1.9 \\
\hline Fusarium sp. & 3 & 4 & 6 & 13 & 1.0 \\
\hline Metarrhizium anisopliae (Metsch.) Sorok. & 3 & 7 & 3 & 13 & 1.0 \\
\hline Mucor hiemalis Wehmer. & 27 & 31 & 36 & 94 & 7.4 \\
\hline Mucor sp. & 4 & 9 & 10 & 23 & 1.8 \\
\hline Paecilomyces farinosus Brown and Smith & 37 & 24 & 47 & 108 & 8.6 \\
\hline Penicillium sp. & 48 & 39 & 62 & 149 & 12.6 \\
\hline Stemphylium sp. & 4 & 3 & 9 & 16 & 1.2 \\
\hline The species of fungi with non-spore mycelium & 11 & 32 & 38 & 81 & 6.3 \\
\hline Total & 347 & 442 & 497 & 1286 & 100.0 \\
\hline
\end{tabular}

After results of the physiological monitoring, from 36.8 to $65.4 \%$ of diapausing caterpillars of the codling moth were infected fungal pathogens of different etiology in consequence of these anomalies. The tactic of reproduction is implemented most fully among of three tactics: reproduction $(R)$, survival $(S)$ and trophic connections $(T)$. The characteristic of life strategies of fungi in the structure of $r$ - and K-continuum showed that tactic of reproduction with typical features of the K-strategist provided most fully in parasitic form, in period of epizootics. The tactics of survival and of trophic connections are characteristic for $r$-strategy. The dynamic of epizootic process is limited in time and manifests monocyclic character with pronounced seasonal manifestation.

The features of development of fungus Paecilomyces farinosus (Dicks. Ex Fr.) Brown et Smith in saprotrophic conditions were studied in more detail. Its development on dead organic substrate 
(leaves of fruit crops, diverse forest plantations and dead roots) was noted. The saprotrophic strategy of development of Paecilomyces farinosus involves the formation of diverse microbial associations with other microorganisms.

As shown earlier (Pleshanova, 1970), the dominant type of relationships between muscardine fungi and soil microflora is fungistatic alimentary antagonisme, in the process of which occurs trophic and ecological expansion of one species in relation to another. Based on the conducted researches was established, that muscardine fungi are characterized by signs of K-selection, suppressing the spread of other fungal entomopathogens. The phenomenon of expansion is manifested most fully in Paecilomyces farinosus. The test characteristics of tactics of reproduction and trophic connections showed distinct tendency to K-selection that acts only through differential success in reproduction (Pianka, 1972).

The ecological adaptation and plasticity of Paecilomyces farinosus in saprophytic conditions is manifested clearly in spreading of the pathogen in ecosystems of exclusion zone of the Chernobyl nuclear power plant. It promotes growth of conidiophores on surface of the organic substrate with positive reaction to light.

As vector of the pathogen in ecosystems is wind and rain. A special role in the spreading of fungal infection belongs to insects. The role of certain entomophages, in particular larva and adult of the ectoparasite Habrobracon hebetor Say., larvae of Chrysopa carnea L., which transfer spores, was installed. At the same time, in the presence of competition was seen pronounced specialization to trophic substrate. This channeled the vector transition to saprophytes (on plant residues).

The analysis of life strategies and tactics of entomopathogenic fungi, trophically and ecologically related to the codling moth, shown that in process their growth formed regular outbreaks. They are characteristic for opportunistic species. The maximum contribution of matter and energy to the process of reproduction are considered best reproductive strategy. The conducted research gives the opportunity to affirm that for entomopathogenic fungi are characterized by mixed strategies of selection in ecosystems of exclusion zone of the Chernobyl nuclear power plant. In such conditions, the best life strategy is maximum contribution of matter and energy to reproduction for production large quality of biomass in short time. However, the optimal strategy is transformation more quality of energy on overcoming competition in the most saturated habitat with pronounced competition.

\section{Conclusions}

The entomopathogenic fungi, which associated ecologically and trophically with populations of the codling moth in ecosystems of exclusion zone of the Chernobyl nuclear power plant are characterized by the significant species diversity and exposed mainly to $r$-selection on the axis of $r$ - and K-continuum. Among the entire fund of entomopathogens dominates Beauveria bassiana (Bals.) Vuill., with specific weight of $47.9 \%$ in relation to other fungi. The vector orientation of entomopathogens to saprophyticism allows increasing ecological niches, approaching the fundamental. Among three tactics (reproduction, survival and trophic connections) was implemented most fully tactic of reproduction. The dynamic of epizootic process are limited in time and manifests monocyclic character with pronounced seasonal manifestation. 


\section{References}

Drozda, V.F. 2016. Successional adaptation of codling moth (Laspeyresia pomonella L.) populations in the orchards of the Chernobyl Exclusion Zone. Biodiversity after the Chernobyl Aecident. The scientific proceedings of the International network Agro Bio Net. Slovak University of Agriculture in Nitra, Part II, p. 74-78.

Drozda, V.F. 2009. Receipt of ecologically clean harvest of apples by means of optimization of technologies of fruit planting integrated protection in Ukraine (O11). «Opportunities for increased processed fruit consumption through innovative processing and quality management». $17 \mathrm{p}$.

Fassatiova, O. 1957. Laboratorni pokusy s umelon infekci mandelinky hlavackove (Entomoscelis adonidis Pall.) pomoci cutomofaguich hub. Univ. Carol. Biologica, vol. 3, № 3, ss. 269-292.

Ferro, D.N., Sluss, R.R., Bogyo, T.P. 1975. Factors contributing to the biotic potential of the codling moth (Laspeyresia pomonella L.), in Washington. Environmental Entomology, vol. 4, no. 3, p. 385-391.

Ferron, P. 1967. Les champignons entomopathogenes. Ann. Epiphytes, vol. 18, № 3, p. 361-382.

Ignoffo, C. 1967. Possibilities of mass-producing insect pathogens. Insect pathology and microbial control. North-Holland Publish. Co. Amsterdam, p. 91-117.

Jagues, R.P., Mac Lellan, C.R. 1965. Fungal mortality of overwintering larvae of the codling moth in apple orchards in Nova Scotia. Journal of Invertebrate Pathology, vol. 7, no. 3, p. 291-296.

Labonowski, G.S. 1981. Pathogens and parasites recovered from the hibernating larvae of the codling moth Laspeyresia pomonella L. Polskie pismo entomologiczne, vol. 51, p. 163-170.

Macarthur, R.N., Wilson, E.D. 1963. An equilibrium theory of insular zoogeography. Evolution, vol. 17, p. 373-378.

Pianka, E.R. 1972. r- and K selection or b and d selection? Amer. Natur., vol. 106, p. 581-588.

Андросов,Г.К. 1986. Энтомопатогенныегрибы таежных биогеоценозов какагенты биологической борьбы с вредными насекомыми: автореф. дисс. доктора биол. наук. М. 45 с.

Андросов, Г.К., Андросова, Л.Н., Соболева, Л.А. 1981. Экология энтомопатогенных микроорганизмов таежной зоны Европейского Северо-востока. Использование микроорганизмов для борьбы с вредными насекомыми. Иркутск, с. 139-151.

Вейзер, Я. 1972. Микробиологический метод борьбы с вредными насекомыми. М. 576 с.

Виноградова, К.А., Кожевин, П.А. 2011. Взаимоотношения актиномицетов с почвенными грибами и их использование для биологического контроля фитопатогенов. Микология и фитопотология, том 45, вып. 4, с. 289-302.

Гафурова, В.Л. 1971. Микрофлора яблонной плодожорки и перспективы использования патогенных форм в борьбе с этим вредителем: автореф. дисс. канд. биол. наук. Душанбе. 24 с.

Дрозда, В.Ф., Гойчук, А.Ф. 2015. Біорізноманіття лісових екосистем та біологічний захист дібров від лускокрилих фітофагів. Міжнародна конференція «/нноваційний розвиток АПК України: проблеми та ̈̈х вирішення». Житомир, с. 201-205.

Дрозда, В.Ф. 2015. Біорізноманіття, як функція стійкості екосистем: теоретичні аспекти проблеми. Міжнародна наукова конференція «Інтегрований захист та карантин рослин. Перспективи розвитку в ХХІ столітті». НУБіП, М. Київ, С. 198-200.

Дрозда, В.Ф. 2015. Континуальная структура популяций яблонной плодожорки Laspeyresia pomonella L. (Lepidoptera, Tortricidae). Материалы Всероссийской конференции «Биогеосистемная экология и эволючионная биогеография». Новосибирск, с. 56-58.

Дрозда, В.Ф., Сагитов, А.О., Кочерга, М.А., Копжасаров, Б.К. 2014. Технологические особенности защиты яблоневых садов от яблонной плодожорки Laspeyresia pomonella L. (Lepidoptera, Tortricidae) в садах Украины и Казахстана. Казахский НИИ защиты растений. ВПРС МОББ. 
Материалы международной научной конференции. В сб. «Защита растений и экологическая устойчивость агробиоченозов». Алматы, с. 65-67.

Дрозда, В.Ф., Сагитов, А.О. 2015. Характеристики жизненных стратегий карпофагов в контексте защиты садов в условиях Украины и Казахстана. Международная научная конференция «Инновачионные экологически безопасные технологии защиты растений». Казахстан. Алматы, с. 98-108.

Евлахова, А.А. 1974. Энтомопатогенные грибы. Систематика, биология, практическоезначение. Л.: Изд-во «Наука». 260 с.

Евлахова, А.А., Швецова, О.И. 1966. Задачи исследований по микробиологическому методу борьбы с вредными насекомыми. Журнал общ. биол., т. 27, № 4, с. 448-456.

Кожевин, П.А. 2004. Экология почвенных микроорганизмов. Экология микроорганизмов. М.: Академия. 273 с.

Красильников, Н.А. 1958. Микроорганизмы почвы и высшие растения. М.: Изд-во АН СССР. 463 с.

Плешанова, Г.И. 1970. Энтомопатогенный гриб Paecilomyces farinosus Dicks. ex Fr. Brown et Smith и возможности использования его против вредителей леса: автореф. дисс. канд. биол. наук. Иркутск. 26 с.

Чулкина, В.А. 1991. Биологические основы эпифитотиологии. М.: Агропромиздат. 278 с. 